\title{
レアメタルを含む金属資源の概要
}

\author{
北良行 ${ }^{a}$, 大久保 聡 $^{\mathrm{a}}$ \\ a (独)石油天然ガス・金属鉱物資源機構 ( ( 105-0001 東京都港区虎ノ門 2-10-1 虎ノ門ツインビルディング西棟)
}

\section{Rare Metal, Its Exploitation and Resource Policy}

\section{Yoshiyuki KITA a and Satoru OKUBO ${ }^{\text {a }}$}

${ }^{a}$ Japan Oil, Gas and Metals National Corporation (JOGMEC)(Toranomon Twin Building, 2-10-1, Toranomon, Minato-ku, Tokyo 105-0001)

Keywords : Rare Metals, Rare Earth, Exploration, Recycle, Mineral Strategy

\section{1.はじめに}

本稿ではレアメタルを含む金属資源の開発・生産および金 属の利用といった産業構造につき概略的に述べ, 金属資源を 巡る現況, レアメタルの供給上の問題点と現在講じられてい る政策について若干ふれる。

\section{2.レアメタルとは}

近年,「中国・レアアース」という言葉が紙面を賑わせて いる。レアアースとはレアメタルといわれる金属の一種で, ランタノイド(原子番号 57 ランタンから, 71 ルテチウムま での 15 の元素) にスカンジウムとイットリウムを加えた 17 の元素の総称である。これらの元素は, 磁石や蛍光剤など産 業に欠かせない重要な金属である。

金属はベースメタル，貴金属などという呼び方がされてい る。ベースメタルには銅, アルミニウム, ニッケル, 鉛, 垔 鉛が含まれる。鉄関係では鉄そのものと, 鉄鋼を生産するの に不可欠な添加剤であるマンガンやステンレスの添加剤とな るクロムやバナジウムなどがありフェロアロイ(合金として 使われる)と呼ばれている。これらの金属は比較的需要量が 多い。使用量が少ないが産業に欠かせない金属はマイナーメ タルと呼ばれている。日本ではほほ同意語としてレアメタル といわれる。貴金属(プリシャスメタルもしくはノーブルメ タル)は比較的高価な金属で, 一般には金, 銀, プラチナ族 金属 (Pt, Pd, Rh, Ru, Ir, Os)を指す。このほか, アメリカ を中心に, 産業に欠かせない金属の総称をクリティカルメタ ルと称し資源の議論が行われている。

なお, 以上に説明した金属の呼び名は, 資源や経済面から 使われるようになったもので, 貴金属以外の分類に科学的意 味は無い。

\section{3. 金属資源開発の流れ}

金属資源開発は原油, 石炭の場合と同様, 資源の発見から 生産開始まで早くても 10 数年を要するリード夕イムの長い ビジネスである。また, 自然が相手のため, 思わぬトラブル
が生じることも多い。金属を生産するにはそれが濃集して存 在する集合体を確認しなければならない。この金属の存在を 確認することを探鉱と呼んでいる。この地殼中にあって天然 資源として有用な鉱物・流体などが特に濃集した集合体は鉱 床と呼ばれる。探鉱で経済性のある資源が確認されると, 生 産のため鉱山として開発が進められる。ここでは, 金属など が胚胎する鉱床がどのように探し出され，開発されるかにつ いて説明を行う。

\section{1 金属資源探査}

まず我々は，金属元素が経済的に採取できる金属資源の状 態まで濃集した場である「鉱床」を探すことになる。例えば, 鉱床を形成するためには, 鉄, アルミなどは地殼存在度の数 倍, その他の金属では数百倍〜数千倍まで濃集されているこ とが必要となる。このような濃集は地質・地形など, 一定条 件下で起きる現象であるため, 鉱床は特定の場所に形成され, 結果として偏在することになる。

かつて，探鉱は，いわゆる山師といわれる技師が地面に金 気という兆候を探すことから始まった。踏査(山を歩き回る) と言われる方法であるが, 現在では踏査をきっかけにした直 接地表に兆候が見える鉱床発見はほとんどしつくされたと言 われている。そこで 20 世紀後半からは, 科学技術を駆使し 地表から直接見つけにくい潜頭性の鉱床の探鉱が行われるよ うになった。探鉱では対象となる地域にどれだけの情報が蓄 積されているかで，個々の地域での探鉱手順は異なってくる。 理論的には衛星や航空機などで取得されたデー夕, 地表部か ら物理的特性や化学的特性の測定を通じて行う調査, 試錐調 査, 坑道調査をへて, 事業化調査 (FS)の評価を行い開発が 始まる。また, 開発の対象となる鉱石が経済的に加工可能で あるかといった選鉱・製錬試験, 環境影響調査も合わせて行 われる。資源探査の流れを図 1 に示す。

\section{2 金属資源の生産}

金属の生産には鉱山から直接生産される 1 次生産と, いわ ゆるリサイクルなどの 2 次生産がある。

3. 2. 11 次生産(鉱山生産)

一般に鉱山から生産されるものをさす。採鉱，選鉱，製・ 


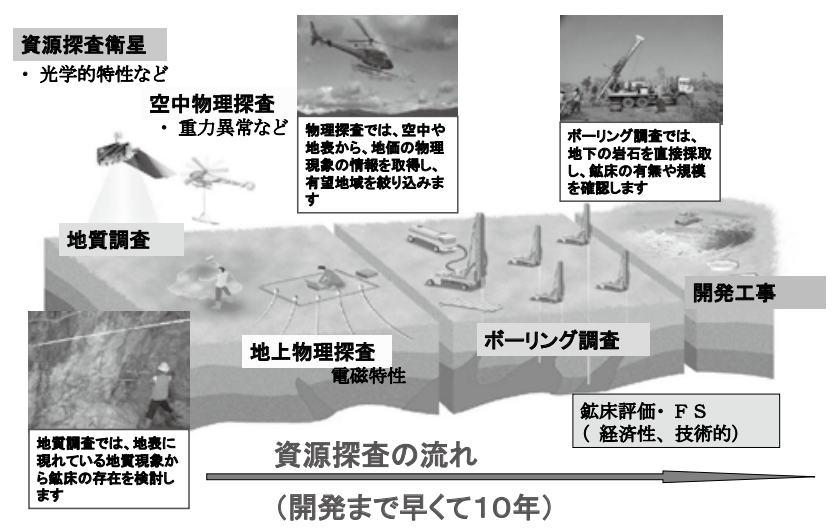

図 1 資源探査の流れ

精錬を経て金属が生産される。ここでは銅の生産を例に説明 する。採鉱では坑内掘りと露天掘りがある。また，製錬では 従来法では乾式製錬 (自溶炉)が主流であるが, 現在は湿式精 錬(化学的な手法)が取り入れられる場合がある。

これらの工程で金属は徐々に純度が高められていく。例え ば銅の場合，採鉱の段階では鉱石に含まれる銅分は $1 \%$ に 満たないが，選鉱の段階で $20 \sim 30 \%$ に濃縮され，製錬の 段階で $99 \%$ 以上まで高められ，最終的には精錬で $99.99 \%$ 以上の純度 (LME 基準)にまで加工される。鉱山開発と金属 生産の流れを図 2 に示す。

(1)採 鉱

採鉱では, 金属含有量 (品位), 鉱床の形状・場所・深度な どに応じ，最適な方法が選定される。大きく分けて坑内採掘 と露天掘りがあり，基本的には高品位濃集型の鉱床の開発が 前者で，大型低品位型の鉱床の開発が後者となることが多い。 銅鉱石の場合，鉱床での銅の含有量は一般的に $1 \%$ 程度以 下であるため，年間 50 万トンの銅を生産する大規模な露天 掘り銅鉱山では，一日で 10 万トン以上もの鉱石が採掘され ている。この段階の鉱石を粗鉱と呼ぶ。なお，鉱石を採掘す
るためにはズリといわれる周辺の岩石なども採掘しなければ ならない。

(2)選 鉱

採掘された鉱石は選鉱場に送られ，粉砕，磨鉱のうえ有用 鉱物とそうでないものに分離される。この工程を選鉱と言い, 有用金属の回収率を高めるため鉱石を粒径数 $10 \mu \mathrm{m}$ 程度ま で細かくする。選鉱は磁力や重力などを活用して行われるが, 銅鉱山の場合，浮遊選鉱という手法を用いる。分離された有 用鉱物を精鉱と呼ぶ。銅精鉱の銅含有量(品位)は $20 \sim 30 \%$ 程度となる。有用鉱物は黄銅鉱など硫化物の集合体である。

なお，現在銅生産の主力であるポーフィリーカッパー鉱山 では，この段階でモリブデン精鉱を分離・回収している。

(3)製 錬

精鉱はさらに製・精錬工程に送られ金属に加工される。製 錬は，精鉱を炉で溶かし，硫化物を物理的に有用金属濃集部 (一般にマットと呼ぶ) と不要な金属(スラグと呼び一般には 鉄とシリコンで構成される)に分離する。マットはさらに加 工され，製錬の段階で銅分 $99 \%$ 以上まで高められる。有用 鉱物はほとんどが硫化物であるため, この工程では鉱物に含 まれる硫黄がガスとして分離・排出する。これらは硫酸とし て回収されている。現在加工対象とする鉱石は黄銅鉱などが 主流であるため, 生産される銅と同量のスラグとほぼ倍の硫 酸が発生する。

(4)精 錬

製錬された有用金属は，さらに電気分解により(電解工程), 不純物を取り除き，金属(地金，化合物など)を抽出する。こ の工程によって銅は $99.99 \%$ 以上の銅地金となる。この後, 各分野のメーカーでさまざまな最終製品に加工される。

日本国内には, 現在, 銅鉱山が存在しない。このため, 日 本で製・精錬を行うためには，主な鉱石生産地であるチリ， ペルーにおいて, 鉱山から輸出港までのトラック・鉄道など による陸上輸送，さらに日本までの海上輸送を経て精鉱の状 態で輸入をしている。金属生産までには多くの時間とコスト

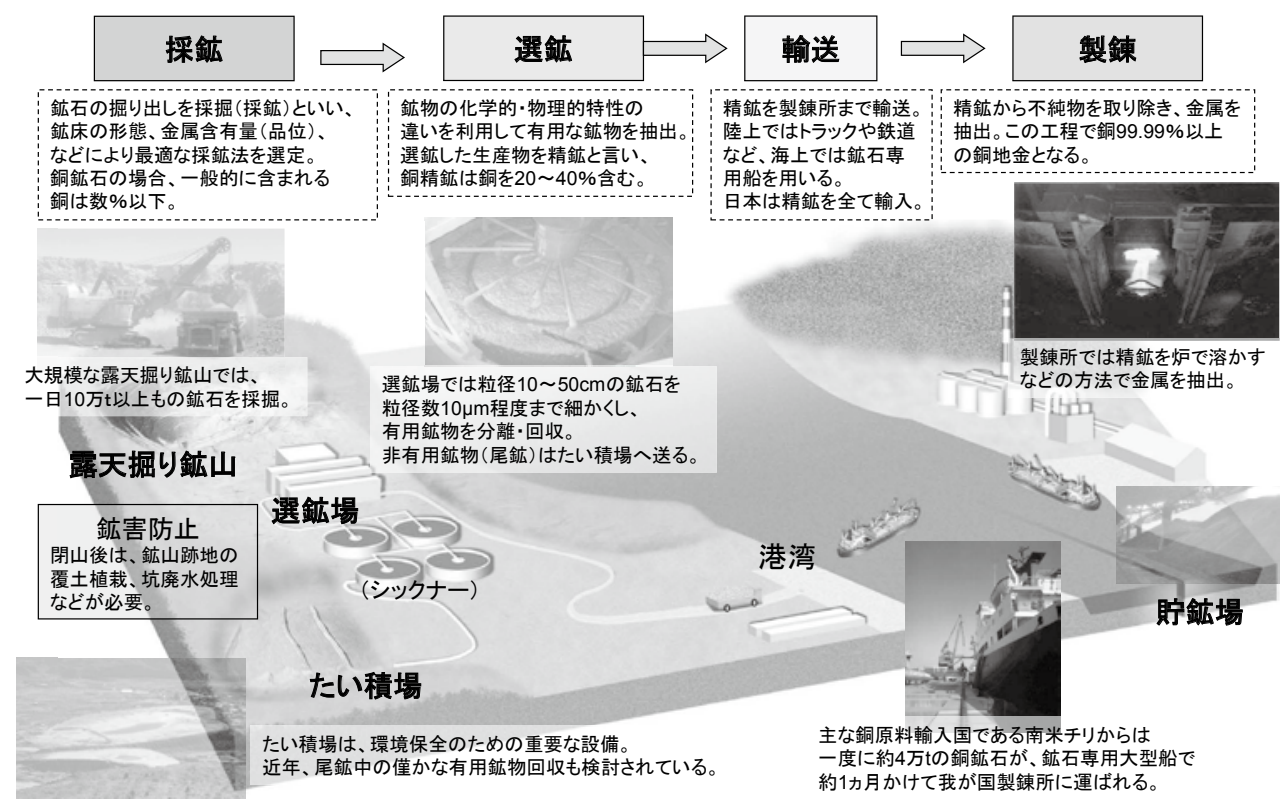

図 2 金属の生産の流れ 
表 1 生産される金属の関係

\begin{tabular}{c|l|l}
\hline \multirow{2}{*}{ 主産物 } & \multicolumn{3}{|c}{ 副産物 } \\
\cline { 2 - 3 } & 鉱山で分離される金属 & \multicolumn{1}{|c}{ 製錬所で分離される金属 } \\
\hline \multirow{2}{*}{ 銅 } & モリブデン, コバルト & $\begin{array}{l}\text { 金, 銀, セレン, テルル, 白 } \\
\text { 金族金属 (プラチナ, パラジ } \\
\text { ウム等) }\end{array}$ \\
\hline 亜鉛 & 鉛 & $\begin{array}{l}\text { 金, 銀, カドミウム, インジ } \\
\text { ウム, ゲルマニウム, (ガリ } \\
\text { ウム })\end{array}$ \\
\hline 鉛 & 亜鉛 & $\begin{array}{l}\text { 金, 銀, ビスマス, アンチモ } \\
\text { ン, ゲルマニウム }\end{array}$ \\
\hline ニッケル & - & $\begin{array}{l}\text { コバルト, 白金族金属 (プラ } \\
\text { チナ, パラジウム等 })\end{array}$ \\
\hline 鉄 & バナジウム, レアアース & \\
\hline
\end{tabular}

が費やされている。

これらの生産工程では, 採掘・選鉱工程でズリ, 製・精錬 工程ではスラグが不要物として大量に発生する。一方，製錬 工程では硫酸が, 電解工程からは, さらに処理が必要ではあ るが, 金, 銀, テルル, セレンなどが含まれ, 副産物として 回収されている。

3. 2. 2 2 次生産(リサイクル)

リサイクルは，精製工程でのマテリアルや一度市中に出 回った製品などから回収するシステムがある。これらは都市 鉱山と呼ばれる場合がある。対象とする金属, 回収したい製 品ごとに大きく流通形態が違い, 現在でも開発の余地が大き い金属がある。ちなみに, 銅や鉛はリサイクルからの供給率 が比較的高く，一方，同じベースメタルでも亜鉛は低い。

3. 2. 3 副産物としてのレアメタル

鉄鋼関係の金属 (フェラスメタル)は単独で開発されること が多いが，非鉄金属はそのもの単独で開発することは稀で, 複数の金属が組み合わされて生産されることがほとんどであ る。上述したように, マイナーメタルの多くがベースメタル の副産物として生産されている。副産物には主に鉱山で分離 される金属 (主に選鉱過程) と, 精錬所で分離される金属があ る。表 1 に生産される金属の関係の一例を示す。
銅を例にすれば，モリブデンは山元の選鉱所で分離・生産 され，セレン，テルルなどは精錬所で分離される。また，亜 鉛精錬ではインジウム, ガリウム, カドミウム, ビスマスな どが分離される。ニッケルからはコバルトのほかプラチナ族 金属が生産される。

\section{4. 金属の消費}

鉄, アルミニウム, 銅, 鉛, 亜鉛, 錫などのベースメタル は産業の基礎資材として利用され，日本の産業基盤および経 済のために極めて重要である。日本が得意とする自動車やエ レクトロニクス産業や, 再生可能エネルギー産業やそれらを 支える部素材には, 環境性能の向上や省電力化, 小型 - 軽量 化，高機能化，耐久性向上などが求められており，これらの 実現のためには, レアメタルなどの安定確保が必要不可欠で ある。産業分野に必要なレアメタルを表 2 に示す。

以下，主要な金属の用途を述べる。

\section{1 ベースメタル}

(1)鉄は最も多量に, また広く利用されている金属で, 建築・ 土木, 自動車, 船舶, 産業機械など多岐にわたり基礎材料と して用いられる。耐食性, 耐酸性を錆びやすかったり, 用途 によっては強度が十分でないため，バナジウムやモリブデン， クロムやニッケルを添加してステンレスとして使用されるこ ともある。

(2)アルミニウムは軽い金属の代表で, 工業生産されて約 100 年と実用の歴史が比較的浅い金属である。自動車, 航空機, サッシ，飲料容器に用いられる。電気を多量に消費する製造 工程から「電気の缶詰」と呼ばれ，またそのためリサイクル が進んでいる。

(3)銅は人類が最も古くから利用している金属で, 導電性, 熱伝導性が高く, 加工性に優れている。電線，伸銅品銅箔と して使用されている, 電力, 建築のほか, 電子機器の基盤や, 自動車のワイヤーハーネスなど，広い産業分野で用いられて

表 2 産業分野に必要なレアメタル

\begin{tabular}{|c|c|c|c|}
\hline 産業分野 & 構成部品 & 構成材料 & 主要レアメタル \\
\hline \multirow{3}{*}{ 製鋼業 } & 普通鋼 & & $\mathrm{Mn}$ \\
\hline & 特殊鋼 (ステンレス等) & & $\mathrm{Ni}, \mathrm{Cr}, \mathrm{Mn}, \mathrm{Mo}, \mathrm{Nb}, \mathrm{Ti}$ \\
\hline & スーパーアロイ & & $\mathrm{Ni}, \mathrm{Cr}, \mathrm{Co}, \mathrm{Mo}$ \\
\hline \multirow[t]{2}{*}{ 原子力 } & 設備 (炬心容器, 構造物等) & $\begin{array}{l}\text { 炭素鋼, 低合金鋼, チタン合金, } \\
\text { スーパーアロイ } \\
\end{array}$ & Cr, Ni, Mn, Ti, Mo \\
\hline & 燃料被覆管 & ジルコニウム合金 & $\mathrm{Zr}$ \\
\hline 航空機 & 機体, エンジン, 機構部品 & $\begin{array}{l}\text { チタン合金, スーパーアロイ, } \\
\text { アルミ合金等 }\end{array}$ & Cr, Ni, Mn, Ti, Mo, Nb, Mg, V, Zr \\
\hline 宇宙 & ロケット(エンジン, 推進薬タンク) & $\begin{array}{l}\text { スーパーアロイ, アルミ合金, } \\
\text { チタン合金 }\end{array}$ & Cr, Ni, Mn, Ti, Mo, Nb, Mg, V, Zr \\
\hline ロボット & サーボモー夕 & ネオジム磁石 & Nd, Dy \\
\hline 超伝導 & 電送ケーブル, 産業用モータ等 & 超伝導材料 ( $\mathrm{Bi}$ 系, $\mathrm{Y}$ 系, $\mathrm{NbTi}$ 系, $\mathrm{NbSn}$ 系) & $\mathrm{Bi}, \mathrm{Y}, \mathrm{Gd}, \mathrm{Ce}, \mathrm{Nb}, \mathrm{Ti}$ \\
\hline \multirow{2}{*}{ 自動車 } & $\begin{array}{l}\text { 既存自動車(部品，金型，工具） } \\
\text { (三元触媒) }\end{array}$ & $\begin{array}{l}\text { 普通鋼, 特殊鋼, アルミ合金 } \\
\text { 触媒及び助触媒 }\end{array}$ & $\begin{array}{l}\text { Ni, Cr, Mn, W, Co, Mo, V, Mg, Nb } \\
\text { Pt, Pd, Rh, Ce, La, Zr }\end{array}$ \\
\hline & $\begin{array}{l}\begin{array}{l}\text { 次世代自動車 (モータジェネレータ) } \\
\text { (二次電池) }\end{array} \\
\end{array}$ & $\begin{array}{l}\text { ネオジム磁石 } \\
\text { 正極材, 負極材, 電解質 }\end{array}$ & $\begin{array}{l}\text { Nd, Dy } \\
\text { Ni, Co, Mm, Mn, Li, Y }\end{array}$ \\
\hline \multirow{5}{*}{ 電気·電子機器 } & MLCC & 誘電体 $\left(\mathrm{BaTiO}_{3}\right.$, 添加剤 $), \mathrm{Ni}$ 電極 & Ti, Ni, Ho, Dy, Ce, La, Y, Er, Gd \\
\hline & 白色 LED & 蛍光体 (YAG, その他) & $\mathrm{Y}, \mathrm{Ce}, \mathrm{Gd}, \mathrm{Sm}, \mathrm{Eu}$ \\
\hline & LCD パネル & 透明電極(ITO), ゲート電極 & In, $\quad$ Cr, Ta \\
\hline & リチウムイオン二次電池 & 正極材, 電解質 & $\mathrm{Ni}, \mathrm{Co}, \mathrm{Mn}, \mathrm{Li}$ \\
\hline & 振動モータ, VCM, コンプレッサモータ & ネオジム磁石 & Nd, Dy \\
\hline \multirow{2}{*}{$\begin{array}{l}\text { ライフ } \\
\text { サイエンス }\end{array}$} & 生体材料 & チタン合金, 純チタン, コバルトクロム合金 & Ti, Co, Cr \\
\hline & 歯科金属材料 & $\begin{array}{l}\text { 金銀パラジウム合金, コバルトクロム合金, } \\
\text { 人工歯根 (チタン合金), 銀合金 }\end{array}$ & $\mathrm{Pd}, \mathrm{Pt}, \mathrm{In}, \mathrm{Co}, \mathrm{Cr}, \mathrm{Ni}, \mathrm{Ti}, \mathrm{V}, \mathrm{Mo}, \mathrm{Nb}$ \\
\hline
\end{tabular}


いる。

(4)鉛は自動車用など鉛蓄電池の原料として重要な金属であ る。その他, 無機薬品にも用いられる。

(5)亜鉛は鉄の防食に欠かせない金属で自動車用防錆鋼板, 亜鉛めっきに用いられる。

\section{2 レアメタル}

(1)ニッケルは大部分がステンレス鋼向けで, その他スー パーアロイ(耐熱合金), 電池材料としても用いられる。多く の素材のめっきにも不可欠である。

(2)マンガン, クロム, モリブデン, バナジウムはフェロア ロイ (合金鉄) と呼ばれ, 鉄鋼添加元素として重要である。マ ンガンは製鋼や張力鋼生産に, また, クロムはニッケルとと もにステンレス生産の重要原料となっている。モリブデン, バナジウムは鉄の防食性, 耐熱性などを増長させるために不 可欠である。

(3)タングステンは最も融点が高く硬い金属 $\left(3,400{ }^{\circ} \mathrm{C}\right)$ で, 中国が世界の約 $80 \%$ を生産している。かつては白熱電球に 使われていたが, 自動車部品や電気機器などの作製・加工に 使われる超硬工具, 鉱山・土木用機材として産業一般に利用 されている。

(4)レアアース (希土類) はランタノイド 17 元素の総称で, 光学特性や電磁特性など, その特異な物理特性に着眼して, 希土類磁石 $(\mathrm{Nd}, \mathrm{Dy})$, 研磨材 (Ce), 蛍光体 ( $\mathrm{Y}, \mathrm{Eu}, \mathrm{Tb})$, 光学ガラス $(\mathrm{La}, \mathrm{Y})$, 触媒 $(\mathrm{Ce}, \mathrm{La})$ に用いられる。重希土類 と軽希土類に分類され，一部の高性能希土類磁石に必要な Dy は現在中国でしか経済的な生産がされていない。全体で も中国が世界生産の約 $90 \%$ を超える。

(5)金属チタン (チタン展伸材) は軽くて強い金属で, 耐熱, 耐食性が優れており, 航空機, 宇宙産業, 海水淡水化プラン 卜，人工関節に用いられる。現状では，アルミニゥム以上に 精錬に多大なエネルギーを要する。航空産業, 特にボーイン グ 787 や，中東の淡水化プラントでの需要が伸びている。

(6) リウムは炭酸リチウムとして, リチウム・イオン電池 の原料(正極材, 電解質など) として需要が急増している。主 に, かん水鉱床から生産される。中国を除くとチリ，アルゼ ンチン, オーストラリアに生産が集中, 生産企業も 3 社と寡 占化が進んでいる。

(7)プラチナ族金属 (PGM : Pt, Pd, Rh， Ru，Ir， Os)は,
自動車廃棄ガスなど触媒 $(\mathrm{Pt}, \mathrm{Pd}, \mathrm{Rh})$, 宝飾品 $(\mathrm{Pt}, \mathrm{Pd})$, $\mathrm{HDD}$ など電子産業 $(\mathrm{Pd}, \mathrm{Ru})$, 歯科用 $(\mathrm{Pd})$ 材料として用いら れる。また，LEDのサファイヤ基盤製作に使うるつほ (Ir)や 精密ガラス生産機材 $(\mathrm{Pt})$ に不可欠な元素である。生産国が限 られ，特にプラチナは南アフリカに生産が集中している。

生産量は鉄鉱石が 20 億トン弱と群を抜いているが, アル ミニウム, クロム, マンガンは原料ベースで 3 〜 千万トン, 代表的なべースメタルである銅, 亜鉛, 鉛は金属ベースで 1 〜 2 千万トン程度, ニッケルが 170 万トン程度である。これ に対して，タングステン，コバルトなどのマイナーメタルは， 数万〜十万トンである。また貴金属である金は 2,500 トン, プラチナは 200 トン程度とぐっと少量になる。表 3 に世界の 金属消費量, 鉱山からの生産量を表 4 に示す。

\section{5. 金属の取引}

一般になじみがある金属の取引は貴金属取引である。これ には現物取引と先物取引がある。実際に商品の移動をともな う受渡しが行われるケースもあるが, 一般的には倉荷証券と 呼ばれる，有価証券と代金の授受をもって受渡しを行うなど 現物商品の移動をともなわない取引が多い。現在, 金の主要 な現物市場では，相対取引によりロンドンやニューヨークな どに事務所を置く取引業者間で活発な商いが行われている。 一方, 主要な先物市場はニューヨークのマーカンタイル取引 所 : NYMEX (New York Mercantile Exchange) と東京工業品取 引所である。

このような取引のベースメタル版がロンドン金属取引所 (LME) である。LME は, 銅・鉛・亜鉛・ニッケル・錫・ア ルミニウムなど非鉄金属取引の世界的な中心であり，その取 引価格を公表することにより，非鉄金属の国際価格をリード する役割(機能)を担っている。

一方で, このような公開された取引の他に, 供給者と需要 家の契約ごとに值決めを相対で実施する金属も少なくない。 多くのフェラスメタル，マイナーメタルがこれに属する。需 給状況, 契約期間, 取引量, 直近の他社などが行った取引情 報などを加味して， 決定する。取引に関する情報を調查し毎 週, 取引価格(スポット)を Metals Week などの金属専門誌が 掲載，価格指標とされている。

表 3 世界の金属消費量

\begin{tabular}{|c|c|c|c|c|c|c|c|c|c|c|c|c|c|c|}
\hline \multirow{2}{*}{ 鉱 種 } & \multirow{2}{*}{ 単位 } & \multirow{2}{*}{ 年 } & \multirow{2}{*}{$\begin{array}{c}\text { 消費量 } \\
(\mathrm{A})\end{array}$} & \multicolumn{3}{|c|}{ 第 1 位消費国 } & \multicolumn{3}{|c|}{ 第 2 位消費国 } & \multicolumn{3}{|c|}{ 第 3 位消費国 } & \multicolumn{2}{|c|}{ 上位五力国計 } \\
\hline & & & & 国 名 & 消費量 & $(\%)$ & 国 名 & 消費量 & $(\%)$ & 国 名 & 消費量 & $(\%)$ & 消費量 (B) & $\mathrm{B} / \mathrm{A}(\%)$ \\
\hline ニッケル & 千 MT & 2010 & $1,511.5$ & 中 国 & 561.5 & 37.1 & 日 本 & 177.0 & 11.7 & 韓 国 & 118.8 & 7.9 & $1,058.8$ & 70.0 \\
\hline クロム & 千 MT & $2007 \mathrm{e}$ & 21,017 & アジア & 9,405 & 44.7 & CIS & 4,794 & 22.8 & アフリカ & 4,458 & 21.2 & 20,653 & 98.3 \\
\hline マンガン & 千MT & 2006 & 19,062 & 中 国 & 10,300 & 54.0 & 南アフリカ & 2,100 & 11.0 & ブラジル & 1,900 & 10.0 & 16,349 & 85.8 \\
\hline コバルト & MT & 2010 & 61,000 & 中 国 & 20,000 & 32.8 & 日 本 & 14,000 & 23.0 & 欧 州 & 10,000 & 16.4 & 54,000 & 88.5 \\
\hline タングステン & MT & 2010 & 69,000 & 欧 州 & 18,000 & 26.1 & アメリカ & 7,000 & 10.1 & 日 本 & 6,000 & 8.7 & 31,000 & 44.9 \\
\hline モリブデン & 千MT & 2010 & 159.6 & 欧 州 & 51.9 & 32.5 & アメリカ & 33.9 & 21.2 & 日 本 & 25.1 & 15.7 & 110.9 & 69.5 \\
\hline バナジウム & MT & 2010 & 102,965 & 中 国 & 27,442 & 26.7 & 西 欧 & 16,239 & 15.8 & アメリカ & 14,515 & 14.1 & 76,476 & 74.3 \\
\hline アンチモン & MT & 2005 & 145,000 & 中 国 & 35,000 & 24.1 & アメリカ & 28,000 & 19.3 & $\begin{array}{ll}\text { 韓 } \\
\end{array}$ & 17,300 & 11.9 & $103,600.0$ & 71.4 \\
\hline プラチナ & MT & 2010 & 246.0 & 欧 州 & 67.0 & 27.2 & 中 国 & 63.5 & 25.8 & 北 米 & 43.5 & 17.7 & 209.9 & 85.3 \\
\hline パラジウム & MT & 2010 & 302.8 & 北 米 & 93.6 & 30.9 & 中 国 & 56.0 & 18.5 & 欧 州 & 56.0 & 18.5 & 251.6 & 83.1 \\
\hline チタン & MT & $2010 \mathrm{e}$ & 146,600 & 中 国 & 57,600 & 39.3 & CIS & 32,000 & 21.8 & アメリカ & 25,000 & 17.1 & 146,600 & 100.0 \\
\hline 希土類 & MT & $2006 \mathrm{e}$ & 108,000 & 中 国 & 59,000 & 54.6 & 日本/東南アジ & 25,750 & 23.8 & アメリカ & 11,500 & 10.6 & 106,000 & 98.1 \\
\hline
\end{tabular}

出典 WMSK ; World Metal Statistics Yearbook 2011, 工業レアメタル Roskill Information Service 他

注 e：推定值 


\section{6. 資源の偏在と生産の集中}

多くの金属資源は生産国が偏り，企業による生産の寡占化 も進んでいる。

\section{1 資源の偏在と資源国の動向}

表 4 鉱山からの生産量をみると, ほとんどのレアメタル は生産国が集中しており，上位 5 力国の生産を合計すると概 ね 80 〜 $90 \%$ を超える。レアアース (中国 $97 \%$ ), タングス テン (中国 $90 \%$ )，アンチモン (中国 $89 \%$ )，ニオブ(ブラジ ル $92 \%)$ ，プラチナ（南アフリカ $75 \%$ ）と 1 カ国に偏在して いる資源が多くもあり，供給源としては脆弱といえる。また， これら生産国では資源の国家管理や課税強化, 資源の高付加 価值化という動きが活発化しており，資源の安定低廉な供給 に支障が出ている。

\section{2 資源メジャーによる生産の寡占化}

金属資源の分野では, Rio Tinto (英国)，BHP-Billiton(英国), Vale (ブラジル), Anglo American (英国), Xstrata (スイス) など，資源メジャーと言われる大企業が存在する。これらの 大企業は全世界において，それぞれが得意な金属資源を対象
として，鉱山開発・生産を手がけてきている。最近の活発な M\&A もあり，これらのメジャーを含めた資源の生産企業寡 占は進んでいる。たとえば 2010 年の鉄鉱石の生産を見ると， Vale, BHP-Billiton, Rio Tinto の上位 3 社 シェアと中国の生 産を含めると $52 \%(39.2 \%)$ となる。その他の鉱種での上位 5 社 (中国を含む)による生産集中は銅 $40 \%(38 \%)$ ，鉛 $65 \%$ $(49 \%)$, 亜鉛 $53 \%(44 \%)$ ，ニッケル $53 \%(49 \%)$, ボーキ サイト $49 \%(46 \%)$ となっており，日本を始めとした需要家 が資源を有利に調達することが極めて困難になっている（括 弧内は 2000 年のシェア)。

\section{7. 鉱物資源における日本の置かれた立場}

\section{1 レアメタル資源の問題点}

これらを背景に，資源を輸入に依存している日本では，資 源国の動向や企業動向の影響を強く受けることになる。表 5 に「我国のレアメタル輸入量」を示す。カナダ，オーストラ リアなども輸入の上位を占めているが，中国が多くの資源で 上位国として存在する。特にタングステン $86.7 \%$, アンチ モン $96.6 \%$ ，レアアース $87.1 \%$ など中国への依存率が異常

表 4 国別生産量

\begin{tabular}{|c|c|c|c|c|c|c|c|c|c|c|c|c|c|c|}
\hline \multirow{2}{*}{ 鉱 } & \multirow{2}{*}{ 単位 } & \multirow{2}{*}{ 年 } & \multirow{2}{*}{$\begin{array}{l}\text { 生産量 } \\
\text { (A) }\end{array}$} & \multicolumn{3}{|c|}{ 第 1 位生産国 } & \multicolumn{3}{|c|}{ 第 2 位生産国 } & \multicolumn{3}{|c|}{ 第 3 位生産国 } & \multicolumn{2}{|c|}{ 上位五力国計 } \\
\hline & & & & 国 名 & 生産量 & $(\%)$ & 国 名 & 生産量 & $(\%)$ & 国 名 & 生産量 & $(\%)$ & 生産量 (B) & $\mathrm{B} / \mathrm{A}(\%)$ \\
\hline ニッケル & 千 MT & 2010 & $1,539.7$ & ロシア & 274.1 & 17.8 & インドネシア & 203.3 & 13.2 & フィリピン & 186.4 & 12.1 & 992.2 & 64.4 \\
\hline クロム & 千 MT & 2010 & 27,387 & 南アフリカ & 10,820 & 39.5 & カザフスタン & 5,092 & 18.6 & インド & 3,852 & 14.1 & 23,279 & 85.0 \\
\hline マンガン & 千MT & 2010 & 39,367 & 中 国 & 11,000 & 27.9 & 南アフリカ & 7,172 & 18.2 & 豪 州 & 6,464 & 16.4 & 30,678 & 77.9 \\
\hline コバルト & MT & 2010 & 76,371 & 中 国 & 32,930 & 43.1 & フインランド & 9,299 & 12.2 & ザンビア & 5,134 & 6.7 & 56,191 & 73.6 \\
\hline タングステン & MT & 2010 & 82,342 & 中 国 & 74,800 & 90.8 & ロシア & 1,800 & 2.2 & ボリビア & 1,518 & 1.8 & 79,914 & 97.1 \\
\hline モリブデン & MT & 2010 & 241,100 & 中 国 & 93,600 & 38.8 & アメリカ & 58,700 & 24.3 & チリ & 37,200 & 15.4 & 217,300 & 90.1 \\
\hline バナジウム & MT & 2010 & 56,000 & 中 国 & 23,000 & 41.1 & 南アフリカ & 18,000 & 32.1 & ロシア & 14,000 & 25.0 & 55,000 & 98.2 \\
\hline ニオブ & MT & 2010 & 63,000 & ブラジル & 58,000 & 92.1 & カナダ & 4,400 & 7.0 & & & & 62,400 & 99.0 \\
\hline タンタル * & MT & 2010 & 670 & ブラジル & 180 & 26.9 & モザンビーク & 110 & 16.4 & ルワンダ & 100 & 14.9 & 495 & 73.9 \\
\hline ゲルマニウム & KG & 2010 & 120,000 & 中 国 & 80,000 & 66.7 & ロシア & 5,000 & 4.2 & アメリカ & 4,600 & 3.8 & 89,600 & 74.7 \\
\hline ストロンチウム & MT & 2010 & 420,000 & 中 国 & 200,000 & 47.6 & スペイン & 180,000 & 42.9 & メキシコ & 30,000 & 7.1 & 418,000 & 99.5 \\
\hline アンチモン & MT & 2010 & 209,789 & 中 国 & 187,400 & 89.3 & タジキスタン & 5,370 & 2.6 & ボリビア & 4,980 & 2.4 & 204,350 & 97.4 \\
\hline プラチナ* & MT & 2010 & 195 & 南アフリカ & 148 & 75.6 & ロシア & 25 & 12.9 & カナダ & 9.6 & 4.9 & 194.1 & 99.3 \\
\hline パラジウム * & MT & 2010 & 197 & ロシア & 87.0 & 44.2 & 南アフリカ & 73 & 37.1 & アメリカ & 12 & 5.9 & 187.6 & 95.2 \\
\hline チタン & 千 MT & 2010 & $4,875.4$ & 豪 州 & 1,186 & 24.3 & 南アフリカ & 800 & 16.4 & カナダ & 780 & 16.0 & 3,535 & 72.5 \\
\hline 希土類 & MT & 2010 & 124,000 & 中 国 & 120,000 & 96.8 & インド & 2,700 & 2.2 & ブラジル & 650 & 0.5 & 123,730 & 99.8 \\
\hline
\end{tabular}

出典 MCS ; Mineral Commodity Summaries 2011 (estimated) *コンゴ民 : コンゴ民主共和国(旧ザイール) WMSY ; World Metal Statistics Yearbook 2011

表 5 我国のレアメタル輸入量

\begin{tabular}{|c|c|c|c|c|c|c|c|c|c|c|c|c|c|c|c|}
\hline \multirow{2}{*}{ 鉱 } & \multirow{2}{*}{ 単位 } & \multirow{2}{*}{ 年 } & \multirow{2}{*}{$\begin{array}{c}\text { 輸入量 } \\
(\mathrm{A})\end{array}$} & \multicolumn{3}{|c|}{ 第 1 位輸入国 } & \multicolumn{3}{|c|}{ 第 2 位輸入国 } & \multicolumn{3}{|c|}{ 第 3 位輸入国 } & \multicolumn{2}{|c|}{ 上位五力国計 } & \multirow[t]{2}{*}{ 備考 } \\
\hline & & & & 国 名 & 輸入量 & $(\%)$ & 国 名 & 輸入量 & $(\%)$ & 国 名 & 輸入量 & $(\%)$ & 輸入量 $(\mathrm{B})$ & $\mathrm{B} / \mathrm{A}(\%)$ & \\
\hline ニッケル & MT & 2010 & 283,628 & インドネシア & 122,645 & 43.2 & フィリピン & 59,437 & 21.0 & ニューカレドニア & 28,852 & 10.2 & 242,864 & 85.6 & \\
\hline クロム & MT & 2010 & 502,992 & 南アフリカ & 213,756 & 42.5 & カザフスタン & 160,845 & 32.0 & インド & 83,663 & 16.6 & 486,484 & 96.7 & \\
\hline マンガン & MT & 2010 & 853,722 & 南アフリカ & 340,250 & 39.9 & 豪 州 & 171,758 & 20.1 & インド & 88,777 & 10.4 & 750,750 & 87.9 & \\
\hline コバルト & MT & 2010 & 13,196 & フインランド & 4,501 & 34.1 & 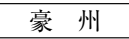 & 2,384 & 18.1 & カナダ & 1,610 & 12.2 & 10,609 & 80.4 & \\
\hline タングステン & MT & 2010 & 3,113 & 中 国 & 2,697 & 86.7 & 豪 州 & 127 & 4.1 & 韓 国 & 76 & 2.4 & 2,974 & 95.6 & \\
\hline モリブデン & MT & 2010 & 26,353 & チ リ & 13,033 & 49.5 & 米 国 & 3,846 & 14.6 & 中 国 & 1,852 & 7.0 & 22,199 & 84.2 & \\
\hline バナジウム & MT & 2010 & 4,834 & 南アフリカ & 2,387 & 49.4 & 中 国 & 1,558 & 32.2 & 韓 国 & 558 & 11.5 & 4,704 & 97.3 & \\
\hline ニオブ & MT & 2010 & 4,929 & ブラジル & 4,669 & 94.7 & カナダ & 167 & 3.4 & 中 国 & 89 & 1.8 & 4,929 & 100.0 & \\
\hline タンタル & MT & 2010 & 695 & 米 国 & 336 & 48.3 & ドイツ & 176 & 25.4 & 夕卜 & 89 & 12.8 & 669 & 96.3 & \\
\hline ゲルマニウム & $\mathrm{KG}$ & 2010 & 19,991 & 中 国 & 11,316 & 56.6 & カナダ & 7,852 & 39.3 & ロシア & 341 & 1.7 & 19,834 & 99.2 & \\
\hline ストロンチウム & MT & 2010 & 18,302 & 中 国 & 8,163 & 44.6 & ドイツ & 5,141 & 28.1 & メキシコ & 4,969 & 27.2 & 18,297 & 100.0 & \\
\hline アンチモン & MT & 2010 & 14,109 & 中 国 & 12,451 & 88.2 & ベトナム & 547 & 3.9 & 夕卜 & 307 & 2.2 & 13,740 & 97.4 & \\
\hline プラチナ & $\mathrm{KG}$ & 2010 & 54,409 & 南アフリカ & 46,756 & 85.9 & 米 国 & 3,241 & 6.0 & スイス & 1,425 & 2.6 & 53,161 & 97.7 & \\
\hline パラジウム & $\mathrm{KG}$ & 2010 & 69,966 & 南アフリカ & 34,748 & 49.7 & ロシア & 20,310 & 29.0 & 英 国 & 5,144 & 7.4 & 66,822 & 95.5 & \\
\hline チタン & MT & 2010 & 218,879 & 南アフリカ & 47,687 & 21.8 & インド & 46,206 & 21.1 & 豪 州 & 39,711 & 18.1 & 176,398 & 80.6 & \\
\hline 希土類 & MT & 2010 & 26,126 & 中 国 & 21,907 & 83.8 & フランス & 1,967 & 7.5 & ベトナム & 697 & 2.7 & 25,306 & 96.9 & $\mathrm{R}_{2} \mathrm{O}_{3}$ 量 \\
\hline
\end{tabular}

出典：日本貿易月表 2010 年 12 月号

出典*：工業レアメタル 2011 (参考値) 
に高いことが伺える。

2000 年になると, 資源市場は, 特に中国の需要が急増し， 金属市場への投機資金が流入したことで，それまでの買い手 有利の市場から, 売り手市場に変化し, また契約が年単位の 長期から四半期単位の短期，スポットへと変化した。 2010 年 9 月の尖閣諸島問題では, レアアースを中心とした 中国の資源輸出に対する態度は大きく世界を震憾させ，資源 の国家コントロールという形で供給障害を引き扢こす政治的 問題としてチャイナリスクが顕在化した。中国では，自国が 有利な立場にある鉱産物である，レアアース，タングステン， アンチモンなどについて，生産制限や輸出制限を行っており， 現在 WTO の場で貿易公正性の議論が行われている。

中国のほか，オーストラリアの資源税，インド鉱石輸出税， インドネシアの鉱業法改正, 南アフリカでの高付加価值化や 鉱山国有化の議論, ジンバブエでの資本現地化比率の引き上 げなど資源ナショナリズム (Resource Nationalism)に関する動 きが活発化している。

\section{2 資源安定供給策}

以上述べたように，資源の安定供給が困難になってきてい る。経済産業省は, 従来総合資源エネルギー調查会の中の鉱 業分科会レアメタル対策部会で総合的なレアメタル安定供 給対策について検討していている。現在，鉱物資源戦略の強 化の方策として資源安定供給対策の 4 本柱として，1)海外探 鉱開発の推進(供給源の多角化), (2)サイクルの推進, (3)代 替材料開発，(4)レアメタルの備蓄をとりあげている。

供給源の多角化については，日本企業への鉱区継承を目的 として,世界各地でベースメタル,レアメタルの探鉱プロジェ クトをJOGMEC が主体的に実施するとともに，資源国と日 本政府間での資源開発に関する協力的関倸の構築が進められ ている。リサイクルについては経済性を勘案したレアメ夕 ル・リサイクルに関する技術開発が経済産業省主導の下実施 されている。代替材料開発についても経済産業省主導の下, レアアース，白金族金属などを対象により安定的な供給が可 能な材料利用に関する技術開発を行っている。また，日本の 産業に重要なレアメタルの一部は国家備蓄が行われている。

平成 22 年 6 月にはエネルギー資源政策の見直しが行われ 自主調達率を含め, 2030 年までにベースメタル $80 \%$, レア メタル $50 \%$ に自給率の向上数值目標が設定された。

さらに, 平成 24 年 6 月には 23 年末にとりまとめられた「日 本再生の基本戦略 (2011 年 12 月 24 日閣議決定)」において
「官民あげた資源獲得に戦略的に取り組む」ことが定められた。 また, エネルギー・環境会議「基本方針」（2011 年 12 月 21 日） に扔いて「資源の安定的な確保のための取組も一層強化する」 と定められ，以下の 5 点に重点的に取り込むとなった。

(1) 資源獲得の重要供給国・地域に対する政府一体となっ た働きかけ

(2) 資源ユーザー産業の上流開発への関与の促進

(3)資源国に対する協力のパッケージ化

(4) 資源権益獲得に対する資金供給の機能強化

(5) 国際的なフォーラムやルールの積極活用

\section{8.まとめ}

2000 年以降, 中国を始めとする BRICs 諸国の需要の高ま りにより金属を含む天然資源の需給構造は激変した。その結 果，資源価格は高騰し，2010 年代に入っても多くの資源の 価格は高止まりした状態である。

特に，資源国として資源を安価で輸出してきた中国は，新 興国として内需拡大で資源を必要とし，多くの金属で輸入ポ ジションとなった。さらに，これまで中国では国内で見過ご されてきた安全刘策，環境対策などを求められるようになっ た。これらを考慮すれば資源価格のベースラインはしばらく 現状が継続すると考えられる。

眼を日本の産業に転じると, 東日本大震災により 2 つの大 きな課題を突き付けられることになった。一つは将来のエネ ルギーが不透明となったことである。もうひとつは，ハイテ ク素材のマテリアルフローの問題が顕在化し日本拠点の生 産・流通はリスクが大きいと膾采され，より強く $\mathrm{BCP}$ (事業 継続計画)がもとめられるようになったことである。これま で自動車や電機産業など資源の需要側は, 資源の供給途絶に 関して自ら策を講じるという認識をしていなかった。これに は資源は供給メーカーが手配するもので，自ら在庫を持たず リスクを納入側に頼って生きた日本のサプライチェーンのあ り方が反映している。このあり方を業界側から改善してゆく ことが求められる。

資源の太宗を輸入する日本にとって資源の確保は国際問題 として取り組む必要もあり, 相手国との協調が益々重要と なってくる。JOGMECをはじめとした官が最大に貢献して ゆくためには供給源の多角化, リサイクルの推進, レアメ夕 ルの備蓄分野での尽力が求められる。

(Received July 31, 2012） 